\title{
THE EFFECTS OF STORAGE TEMPERATURES AND PRETREATMENTS ON THE GERMINATION OF AZAROLE (Crataegus azarolus var. pontica) SEEDS
}

\author{
UTJECAJ TEMPERATURE ČUVANJA I PREDSJETVENE \\ PRIPREME NA KLIJAVOST SJEMENA MUŠMULASTOG \\ GLOGA (Crataegus azarolus var. pontica)
}

Askin GOKTURK', Ethem KARA², Murat Sabri SADIKLAR ${ }^{3}$

\begin{abstract}
SUMIMARY
In this study, which aimed to determine the effects of storage temperatures on the germination of azarole (Crataegus azarolus var. pontica) seeds, pretreatments were applied to the seeds and were dry-stored for 10 months at four storage temperatures $\left(-5,5,15\right.$ and $\left.25^{\circ} \mathrm{C}\right)$ for various periods in floating water and in an ash solution $(2,4$ and 6 days), scarification in sulfuric acid (1, 3 and 6 hours), and combinations of scarification in sulfuric acid and floating in ash solution pretreatments. Also, the scarification rates in the seed coats that were corroded in sulfuric acid for 1,3 and 6 hours were determined. The experimental design was a randomized complete block with four replications. As a result of the study, higher germination percentages $(p<0.05)$ were achieved $(20.95 \%)$ in seeds stored at $15^{\circ} \mathrm{C}$. The results show that the scarification in sulfuric acid is more effective $(\mathrm{p}>0.05)$ on the germination percentage of azarole seeds. The diameters of the seeds that were corroded in sulfuric acid for 1,3 and 6 hours decreased by $6.15 \%, 10.47 \%$ and $11.51 \%$, respectively. To achieve higher germination percentages, azarole seeds should be kept at $15^{\circ} \mathrm{C}$, and exposed to sulfuric acid for 3 hours with 4 day ash solution for sowing in August.
\end{abstract}

KEY WORDS: Azarole, storage temperature, germination barrier, scarification, ash solution

\section{INTRODUCTION}

\section{UVOD}

Hawthorns are a part of the Rosacea family, whose seeds have deep physiological germination barriers (Baskin and Baskin, 2014) caused by an unripe embryo and thick seed coats. Pretreatment must be applied to hawthorn seeds before sowing to eliminate these barriers (Bujarska-
Borkowska, 2007). The general recommendation is to apply warm and cold stratification processes alternately to eliminate germination barriers caused by the immature hawthorn seed embryos (Bujarska-Borkowska, 2007; Morgenson, 2000). However, storage conditions, especially the storage temperature, are important factors in regulating the subsequent after ripening process of unripe seeds. If the seeds are stored at appropriate temperatures, higher germi- 
nation rates can be obtained, as the seeds complete the after ripening process.

The effects of pre-treatments applied to seeds stored at appropriate temperatures to increase the germination rate may be more than previously thought. Otherwise, unsuitable storage temperatures may cause low germination rates, deterioration in seeds and a decrease in seed viability (Schmidt, 2000), consequently the effects of the pre-treatments applied may not be accurately determined.

Appropriate storage temperatures can also increase the water permeability of the seed coats (Wang et al., 2010). The seeds whose coats do not allow water permeation can lose these properties and allow water permeation in dry storage conditions (Gupta and Singh, 1990). These study findings show that appropriate storage temperatures not only eliminate the germination barrier caused by the immaturity of the embryo, but also ensure the removal of the germination barrier caused by the impermeability of the seed coat.

Chemical scarification of the seed coats in sulfuric acid are recommended to eliminate the germination barrier caused by the thick seed coat of hawthorn seeds (BujarskaBorkowska, 2002; Yahyaoglu et al., 2006). Increased water permeability of the seed coat can also be achieved by pretreatment with alkaline chemicals (Hou and Simpson, 1994). Therefore, alkaline ash solution treatments are also recommended (Gokturk and Yilmaz, 2015) to ensure water permeability of the seeds. In order to reveal the actual effects of these proposed pretreatments, it is important to determine the appropriate storage temperature, which is important for the viability of seeds, and to determine the effects of pre-treatments according to storage temperatures. However, there are limited studies to determine suitable storage temperatures for hawthorn seeds.

Hawthorn seeds do not usually germinate in the year the fruit ripens due to germination barriers. With the germination that occurs in the seeds after the warm and cold process under natural conditions shows that the germination rate can be increased if the seeds are stored in warm or hot temperatures.

Azarole (Crataegus azarolus var. pontica (K. Koch K. I. Chr) is one of the hawthorn species represented in Turkey, and is a rare species growing naturally in the provinces of Artvin, the Coruh Valley, Erzurum and Nevsehir in Turkey (Donmez, 2004). Although it is a rare species, it has been the subject of this study due to it being an important income-generating species and the high production demand of its edible fruits by the local inhabitants.

In the present study, the following aims were investigated: (I) Determining the effect of different storage temperatures on germination percentages; (II) Determining the effect of the pretreatments on the germination of the seeds of float- ing in water, floating in an ash solution, scarification in sulfuric acid, and floating in an ash solution + scarification in sulfuric acid; and (III) Determining whether storage temperatures and pretreatments have interactive effects on the germination of the azarole seeds.

\section{MATERIALS AND METHODS MATERIJALI I METODE}

\section{Materials - Materijali}

The azaroleseeds originating fromArtvin and Yusufeli used in the study were obtained from the fruits collected in October 2016 from trees in areas where azarole naturally spreads ( $41^{\circ} 07^{\prime} 00^{\prime \prime} \mathrm{N}, 41^{\circ} 37^{\prime} 48^{\prime \prime} \mathrm{E}, 1150 \mathrm{~m}$, S). The storage and pretreatments of the seeds were performed at Artvin Coruh University, Forestry Faculty Seed and Afforestation Laboratory, and sowing of the seeds was carried out at Ardanuc Forest Nursery ( $41^{\circ} 06^{\prime} 56^{\prime \prime} \mathrm{N}, 42^{\circ} 05^{\prime} 15^{\prime \prime}$ E, 750 $\mathrm{m}, \mathrm{W}$ ) of Artvin Regional Directorate of Forestry.

\section{Methods - Metode}

\section{Extracting Seeds and Determining Seed Characteristics - Vađenje sjemena i određivanje značajki sjemena}

The seeds of the azaroleswere separated from the pulp by wet maceration. Then, the seeds were dried in the shade for 10 days at room temperature $\left(20-25^{\circ} \mathrm{C}\right)$. The determination of moisture content, which is an important factor in seed vitality during the storage duration, was performed before the dried seeds were placed in storage environments. Moisture content was determined by the air-oven method $\left(105^{\circ} \mathrm{C}, 24 \mathrm{~h}\right)$. Seed moisture content was calculated by the
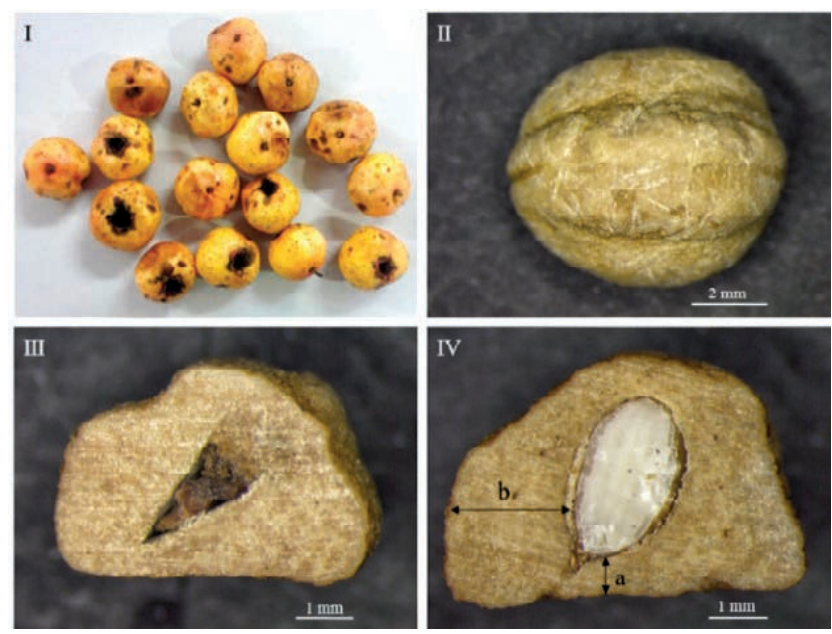

Figure 1. (I) Fruits, (II) seed, (III) empty and (IV) full seed samples, and (a) thinnest and (b) thickest parts of the seeds.

Slika 1. (I) Plodovi, (II) sjeme, primjer (III) praznog i (IV) punog sjemena, i (a) najtanjeg i (b) najdebljeg dijela sjemena 
Table 1. Pretreatments and durations

Tablica 1. Predsjetvene pripreme i trajanja

\begin{tabular}{ll} 
Pretreatments & Duration \\
Predsjetvene pripreme & Trajanje \\
\hline Floating in ash solution (AS) & 2,4 and 6 days \\
Plutanje u otopini pepela (OP) & 2,4 i 6 dana \\
Scarification in sulfuric acid (SA) & 1,3 and 6 days \\
Skarifikacija u sumpornoj kiselini (SK) & 1,3 i 6 dana \\
Floating in water (FW) & 2,4 and 6 days \\
Plutanje u vodi (PV) & 2,4 i 6 dana \\
& 1,3 and 6 hours scarification in sulfuric acid, then floating in ash solution \\
Scarification in sulfuric acid and floating in ash solution (SA + AS) & for 2,4 and 6 days \\
Skarifikacija u sumpornoj kiselini i plutanje u otopini pepela (SK + OP) & 1,3 i 6 sati skarifikacije u sumpornoj kiselini, zatim plutanje u otopini \\
& pepela 2, 4 i 6 dana \\
Control & - \\
Kontrola & -
\end{tabular}

following formula (ISTA, 1993), where MC is moisture content, IW is initial weight and DW is the dry weight.

$$
\mathrm{MC}=((\mathrm{IW}-\mathrm{DW}) \div \mathrm{IW}) \times 100
$$

where; $\mathrm{MC}$ refers to the moisture content, IW refers to the initial weight, and DW refers to the weight after drying.

In the calculation of 1000 seed weights, the average weight calculation method was used in $8 \times 100$ samples (ISTA, 1993). The fill rate was calculated in $3 \times 100$ samples taken from seed weight calculated samples. Coat thickness measurements were made on 100 seeds, that were ground with sandpaper up to half the seed size, by using a digital caliper on the parts where the seed coat was the thinnest and thickest (Figure 1).

\section{Storage of the Seeds - Čuvanje sjemena}

The seeds placed in closed plastic bags can be stored without losing their vitality (Prochazkova and Bezdeckova, 2008). In this study, the dry seeds were placed in storage medium in October 2016 in closed plastic bags with a thickness of 0.04 $\mathrm{mm}$. The seeds were stored at 4 different temperatures as; $-5^{\circ} \mathrm{C}, 5^{\circ} \mathrm{C}, 15^{\circ} \mathrm{C}$ and $25^{\circ} \mathrm{C}$. The seeds were stored in the freezer compartment of a refrigerator at $-5^{\circ} \mathrm{C}$, in the refrigerator at $5^{\circ} \mathrm{C}$, and in incubator with adjustable temperature at $15^{\circ} \mathrm{C}$ and $25^{\circ} \mathrm{C}$. The seeds were kept in storage environments for approximately 10 months until August 2017.

\section{Pretreatments and Experimental Design - Predsjetvene pripreme i plan pokusa}

In the study, floating in water, in ash solution, scarification in sulfuric acid (98\%), and a combination of sulfuric acid and floating in ash solution treatments were made for each storage temperature (Table 1). Ash solution prepared by adding $50 \mathrm{~g}$ oak wood ash in 1-liter water. The $\mathrm{pH}$ value of the solution was 12.5 , and was alkaline. The solution was changed every two days to ensure that the seeds left in the solution had air.

The pretreatments were started on the seeds stored in storage environments for approximately 10 months; and on
August 24, 2017. Sowing was carried out according to complete random blocks with four replications experimental design in polypots at Ardanuc Forest Nursery, Artvin, Tukey; and a total of 30 seeds were used each replication.

\section{Scarification Rates - Stupanj skarifikacije}

The coat thicknesses of hawthorn species might vary among species, even in the same species (Göktürk et al., 2017). Due to this difference in seed coat thickness, the duration of scarification of the seed coat in sulfuric acid ranged between 1 and 3 hours (Bujarska-Borkowska, 2002; Yahyaoglu et al., 2006). This time is up to 6 hours for some hawthorn species with athickseed coat (Dirr and Heuser, 1987). These durations which was recommended for the hawthorn species (i.e. 1, 3 and 6 hours) were used in determining the scarification rates of azarole in sulfuric acid. In the scarification process, $3 \times 10$ seeds were used for all duration of scarification, and the seeds were exposed to scarification by adding $5 \mathrm{ml}$ 95\%-pure sulfuric acid at $1.83 \mathrm{~g} / \mathrm{cm}^{3}$ density in 25 - $\mathrm{ml}$ beakers. Seed diameter and seed length measurements were made twice, before and after the acid scarification process. The following formulas (Göktürk et al., 2017) were used to calculate scarification rates of seed diameter (Sd) and length (Sl):

$$
\begin{gathered}
\mathrm{SRD}=((\mathrm{Sdb}-\mathrm{Sda}) \times 100) / \mathrm{Sdb} \\
\mathrm{SRL}=((\mathrm{Slb}-\mathrm{Sla}) \times 100) / \mathrm{Slb}
\end{gathered}
$$

where SRD is the scarification rate on seed diameter, SRL is the scarification rate on seed length, $\mathrm{Sdb}$ and Slb are seed diameter and length before being treated with sulfuric acid, and Sda and Sla are seed diameter and length values after scarification in sulfuric acid.

\section{Evaluation of Data - Procjena rezultata}

Once the germinations were completed, the germination percentages (GP) of the seeds for each pretreatment were determined. The GP was computed by dividing the number of germinating seeds counted at twice a week from the 
beginning of cotyledon emergence on the soil surface by total number of sown seeds and then multiplying the amount by 100 . The following formula (Ahmadloo et al., 2014) was used to determining GP,

$$
\mathrm{GP}=\Sigma \mathrm{n} / \mathrm{N} \times 100
$$

Where $\mathrm{n}$ is number of seeds that were germinated and $\mathrm{N}$ is total number of sown seeds

The data were evaluated in the SPSS Statistical Package Programs. Since the GP did not show normal distribution, the arcsine square root Conversion $(\sqrt{ } \mathrm{P})$ was applied to the data (Compton, 1994). The Two-Way Variance Analysis (Two Way ANOVA) was used to determine whether there were differences and interactions between storage temperatures and pretreatment for GP. The Duncan Test was used to determine the differences between the groups.

\section{RESULTS AND DISCUSSION REZULTATI I RASPRAVA}

\section{Seed Characteristics - Značajke sjemena}

The moisture content, 1000 seed weights and fill rates of the seeds used in the study were determined to be $9.03 \%$, $201 \mathrm{~g}$ and $55 \%$, respectively. It was determined that the thinnest parts of the seed coat thickness ranged between 0.10 and $3.98 \mathrm{~mm}(0.90 \mathrm{~mm})$; and between 2.01 and $4.14 \mathrm{~mm}$ $(2.96 \mathrm{~mm})$ in the thickest part.

\section{Storage Temperatures - Temperature čuvanja}

The results show that the effect of storage temperature is important on the GP $(\mathrm{p}<0.05)$. Although Bewley et al. (2013) reported that similar germination rates were achieved after storing seeds at room temperature for a few months in species that needed to be exposed to high summer temperatures in natural conditions for germination, in this study, higher germination rate (20.95\%) was achieved in seeds that were stored at $15^{\circ} \mathrm{C}$ (Table 2).

Storage temperature can also ensure that the water permeability of the seed coatis increased (Gupta and Singh, 1990; Bewley et al., 2013; Baskin and Baskin, 2014). The storage temperature of $15^{\circ} \mathrm{C}$ might have increased the permeability

Table 2. GP achieved by storage temperatures

Tablica 2. Postotak klijavosti (PK) u ovisnosti o temperaturi čuvanja

\begin{tabular}{|ll} 
Storage Temperature $\left({ }^{\circ} \mathrm{C}\right)$ & $\mathrm{GP}(\%)^{*}$ \\
Temperatura čuvanja $\left({ }^{\circ} \mathrm{C}\right)$ & $\mathrm{PK}(\%)^{*}$ \\
-5 & $11.32 \mathrm{a}$ \\
5 & $13.36 \mathrm{ab}$ \\
25 & $17.34 \mathrm{bc}$ \\
15 & $20.95 \mathrm{c}$
\end{tabular}

${ }^{*}$ Significantly different at $\alpha=0.05$

*Značajna razlika na $\alpha=0,05$ of the seed coats of azarole. However, Ahmadloo et al. (2017) reported that storage temperatures did not affect the rate of water absorption in the seed coats of hawthorn.

It is already known that the increases detected in the germination rates of dry-stored seeds are caused by the ripening of the embryos of the seeds in the storing process (Bewley et al., 2013). In addition, the effects of the inhibitory substances preventing the germination in the seed coat or embryo during storage are also eliminated (Bell, 1999). For this reason, higher germination rates can be achieved with long storage durations compared to short storage times (Ahmadloo et al., 2015).

It is recommended that orthodox seeds are stored in temperatures below zero, most preferably at $-18^{\circ} \mathrm{C}$ for longer durations without losing their vitality (Hong et al., 1996). In this study, achieving higher GP in seeds stored at $15^{\circ} \mathrm{C}$ compared to seeds stored at $-5^{\circ} \mathrm{C}$ might be associated with the storage durations. Although the storage temperature of $15^{\circ} \mathrm{C}$ had positive effects on the seeds stored for 10 months, this might vary in longer storage durations.

\section{Pretreatments - Predsjetvene pripreme}

As a result of the evaluations made without considering the differences in storage temperatures, it was determined that the effect of pretreatments was significant on the GP of the seeds $(\mathrm{P}<0.05)$. The highest $\mathrm{GP}$ was achieved as $33.31 \%$ in the seeds that underwent $6 \mathrm{~s} \mathrm{SA}+2 \mathrm{~d}$ AS pretreatment (Table 3).

Higher germination results were achieved from the SA pretreatment than from the AS pretreatment. The effect of sulfuric acid on the seed coat was in the form of corroding and thinning the seed coat (Göktürk et al., 2017), and the effect of the ash solution was in the form of removing the inhibitory substances in the seed coat and providing water permeability since it has an alkaline characteristic (Hou and Simpson, 1994). Although not at statistically significant difference percentages, the combination of these two pretreatments compared to the SA process ensuring high GP can be explained by thinning of the coat. However, the fact that high GP were achieved from SA pretreatment compared to the AS pretreatment, and that the GP achieved from seeds that underwent AS did not differ significantly from the GP achieved from the control seeds shows that the germination barrier of azarole seeds is related to the coat thickness.

Scarification in sulfuric acid is the recommended pretreatment to be applied in combination with cold stratification in the elimination of germination barriers (Hartmann et al., 2002). The results obtained in this study show that the optimal scarification time for azarole seeds are 3 hours. The fact that the GP achieved with scarification in sulfuric acid and ash solution combinations did not differ only from the 
Table 3. GP achieved by storage temperature and pretreatments

Tablica 3. Postotak klijavosti (PK) u ovisnosti o temperaturi čuvanja i predsjetvenoj pripremi sjemena

\begin{tabular}{|c|c|c|c|c|c|c|c|c|c|c|}
\hline \multirow{3}{*}{$\begin{array}{l}\text { Treatment } \\
\text { Tretman } \\
\text { 2d AS }\end{array}$} & \multicolumn{8}{|c|}{$\begin{array}{l}\text { GP }(\%) \text { for Storage Temperature }\left({ }^{\circ} \mathrm{C}\right) \\
P K(\%) \text { za temperaturu čuvanja }\left({ }^{\circ} \mathrm{C}\right)\end{array}$} & \multirow{2}{*}{\multicolumn{2}{|c|}{$\begin{array}{l}\text { GP for Treatment* } \\
\text { PK za tretman* }\end{array}$}} \\
\hline & \multicolumn{2}{|c|}{$-5^{*}$} & \multicolumn{2}{|c|}{$5^{*}$} & \multicolumn{2}{|c|}{$15^{*}$} & \multicolumn{2}{|c|}{$25^{*}$} & & \\
\hline & 0,00 & a & 0,00 & a & 0,00 & $\mathrm{a}$ & 0,00 & a & 0 & a \\
\hline $4 \mathrm{~d}$ AS & 0,00 & $\mathrm{a}$ & 0,00 & a & 0,00 & $\mathrm{a}$ & 0,00 & a & 0 & $\mathrm{a}$ \\
\hline 4d FW & 0,00 & a & 0,00 & a & 0,00 & a & 0,00 & a & 0 & a \\
\hline Control & 0,00 & a & 0,00 & a & 0,00 & $\mathrm{a}$ & 6,12 & $a b$ & 1,53 & $a b$ \\
\hline $2 \mathrm{~d} \mathrm{FW}$ & 6,12 & $a b$ & 0,00 & a & 0,00 & a & 6,12 & $a b$ & 3,06 & $a b$ \\
\hline $6 \mathrm{dFW}$ & 6,12 & $a b$ & 8,71 & $a b$ & 0,00 & $\mathrm{a}$ & 6,12 & $a b$ & 5,24 & $a b c$ \\
\hline $1 \mathrm{~h} \mathrm{SA}$ & 0,00 & $\mathrm{a}$ & 6,12 & $a b$ & 6,12 & a & 19,43 & abcd & 7,92 & abcd \\
\hline $6 \mathrm{~d}$ AS & 10,73 & $a b$ & 8,71 & $a b$ & 12,24 & $a b$ & 0,00 & a & 7,92 & abcd \\
\hline $1 \mathrm{~h} S A+2 \mathrm{~d} A S$ & 0,00 & $\mathrm{a}$ & 17,41 & $a b$ & 14,83 & $a b$ & 12,24 & $a b c$ & 11,12 & bcde \\
\hline $1 \mathrm{~h} S A+4 \mathrm{~d} A S$ & 6,12 & $a b$ & 6,12 & $a b$ & 23,53 & $\mathrm{bc}$ & 22,97 & abcd & 14,68 & cde \\
\hline $1 \mathrm{~h} S A+6 \mathrm{~d} A S$ & 19,43 & $a b$ & 0,00 & a & 33,45 & $\mathrm{~cd}$ & 12,46 & $a b c$ & 16,33 & de \\
\hline $3 \mathrm{~h} S A+2 \mathrm{~d} A S$ & 19,43 & $a b$ & 12,24 & $a b$ & 24,70 & $\mathrm{bc}$ & 27,29 & bcd & 20,91 & ef \\
\hline $3 \mathrm{~h} \mathrm{SA}+4 \mathrm{~d} A S$ & 18,58 & $a b$ & 16,85 & $a b$ & 45,80 & $d$ & 27,29 & bcd & 27,13 & $\mathrm{fg}$ \\
\hline $3 \mathrm{~h} S A+6 \mathrm{~d} A S$ & 14,83 & $a b$ & 23,18 & $a b c$ & 34,16 & $\mathrm{~cd}$ & 38,53 & $d$ & 27,67 & $\mathrm{fg}$ \\
\hline $6 \mathrm{~h} \mathrm{SA}$ & 27,57 & $\mathrm{~b}$ & 21,45 & $a b c$ & 38,76 & $\mathrm{~cd}$ & 27,29 & bcd & 28,77 & $\mathrm{fg}$ \\
\hline $6 h S A+4 d A S$ & 14,02 & $a b$ & 30,16 & $b c$ & 39,10 & $\mathrm{~cd}$ & 35,59 & $\mathrm{~cd}$ & 29,72 & $\mathrm{fg}$ \\
\hline $3 \mathrm{~h} \mathrm{SA}$ & 20,95 & $a b$ & 28,14 & bc & 42,98 & $d$ & 34,89 & $\mathrm{~cd}$ & 31,74 & $\mathrm{~g}$ \\
\hline $6 h S A+6 d A S$ & 23,53 & $a b$ & 30,82 & bc & 41,93 & $d$ & 31,89 & $\mathrm{~cd}$ & 32,04 & $\mathrm{~g}$ \\
\hline $6 h S A+2 d A S$ & 27,70 & $b$ & 43,99 & c & 40,37 & $\mathrm{~cd}$ & 21,16 & abcd & 33,31 & $\mathrm{~g}$ \\
\hline
\end{tabular}

*Significantly different at $\alpha=0.05$, Letters indicates differences in columns. "AS" symbolizes ash solution treatments, "FW" floating in water, "SA" scarification in sulfuric acid, $S A+A S$, combinations of ash solution and scarification in sulfuric acid. $d$ and $h$ means day and hour.

*Značajna razlika na $\alpha=0,05$. Slova pokazuju razlike u odnosu na stupce. „AS" simbolizira tretman otopinom pepela, „FW" plutanjem u vodi, "SA“ skarifikacijom u sumpornoj kiselini, „SA+AS“" kombinacijom otopine pepela i skarifikacije u sumpornoj kiselini. d i h označavaju dan i sat.
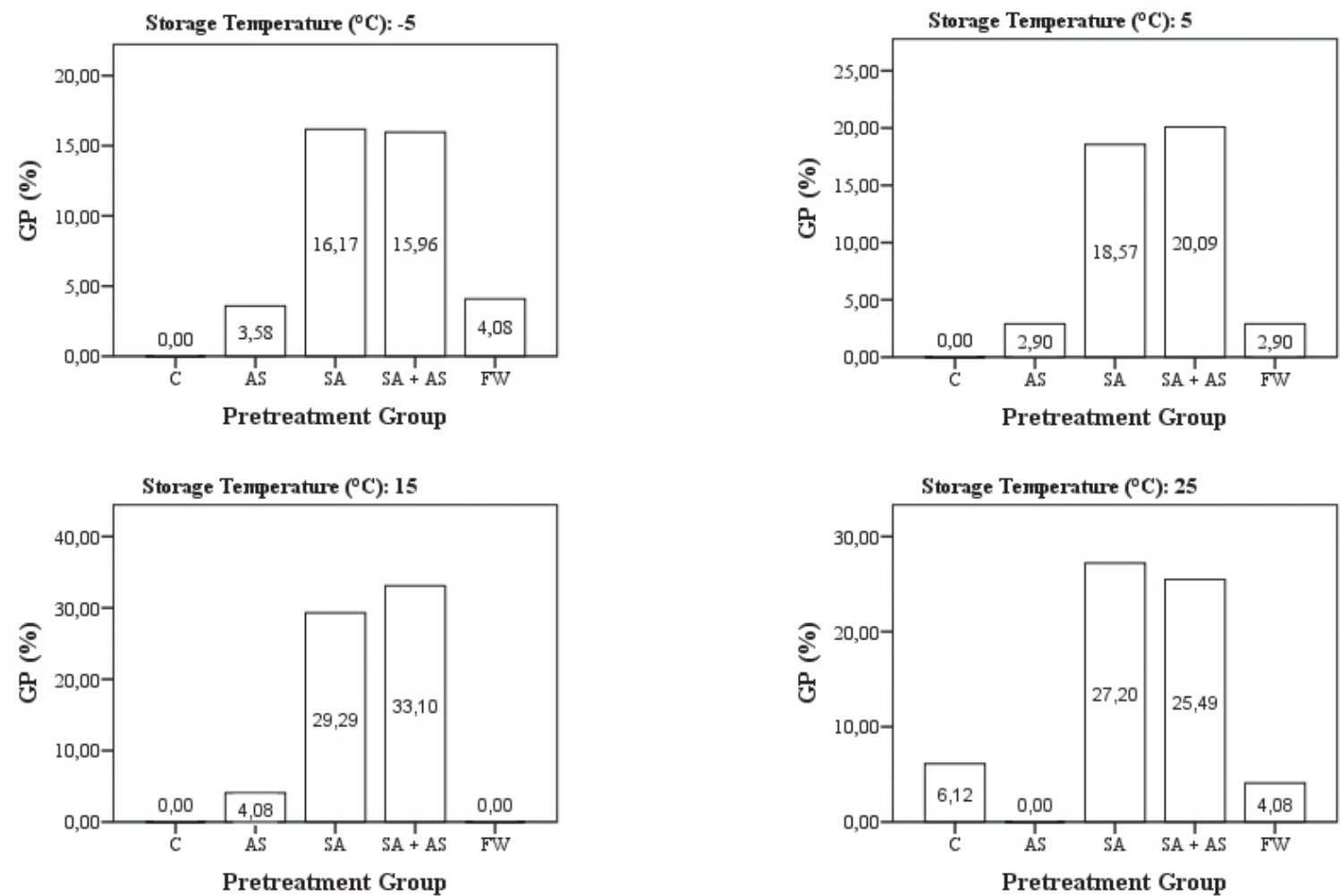

Figure 2. GP achieved by pretreatment groups and storage temperatures $(p<0.05)$

Slika 2. PK utvrđen skupinama predsjetvene pripreme sjemena i temperaturama čuvanja $(p<0,05)$ 
Table 5. Scarification rates in seed diameter and length after acid treatment Tablica 5. Stupanj skarifikacije u promjeru i duljini sjemena nakon tretmana kiselinom

\begin{tabular}{|c|c|c|c|c|c|c|}
\hline \multirow{2}{*}{$\begin{array}{c}\text { Duration (Hour) } \\
\text { Trajanje (sati) }\end{array}$} & \multirow{2}{*}{$\begin{array}{l}\text { Seed diameter } \\
(\mathrm{mm}) \\
\text { Promjer sjemena } \\
(\mathrm{mm})\end{array}$} & \multirow{2}{*}{$\begin{array}{l}\text { Seed length } \\
(\mathrm{mm}) \\
\text { Duljina sjemena } \\
(\mathrm{mm})\end{array}$} & \multicolumn{2}{|c|}{$\begin{array}{l}\text { Scarification }(\mathrm{mm}) \\
\text { Skarifikacija }(\mathrm{mm})\end{array}$} & \multicolumn{2}{|c|}{$\begin{array}{c}\text { Scarification Rate (\%)* } \\
\text { Stupanj skarifikacije (\%)* }\end{array}$} \\
\hline & & & $\begin{array}{l}\text { Seed diameter } \\
\text { Promjer sjemena }\end{array}$ & $\begin{array}{l}\text { Seed length } \\
\text { Duljina sjemena }\end{array}$ & $\begin{array}{l}\text { Seed diameter } \\
\text { Promjer sjemena }\end{array}$ & $\begin{array}{l}\text { Seed length } \\
\text { Duljina sjemena }\end{array}$ \\
\hline 1 & 7.70 & 9.14 & 0.38 & 0.41 & $6.15 a$ & $4.92 \mathrm{a}$ \\
\hline 3 & 7.67 & 9.17 & 0.63 & 0.63 & $10.47 b$ & $8.30 \mathrm{~b}$ \\
\hline 6 & 8.28 & 9.34 & 0.84 & 0.83 & $11.51 \mathrm{c}$ & $9.68 \mathrm{c}$ \\
\hline
\end{tabular}

*Different letters indicate differences $(p<0.05)$ in columns.

${ }^{*}$ Različita slova pokazuju razlike $(p<0,05)$ u stupcima.

seeds that underwent sulfuric acid pretreatment shows that the effect of sulfuric acid was higher.

The treatment of floating in ash solution, which was effective in eliminating the germination barriers in C. orientalis seeds (Göktürk and Yilmaz, 2015), was applied with the idea that it could be effective in azarole seeds, but germination was not achieved. This result may be because of different seed characteristics. The seed size and seed coat thickness of azarole is higher than C. orientalis (Göktürk et al., 2017).

The interactions of pretreatment and storage temperatures on the GP of azarole seeds did not have any significant effects $(p<0.05)$. The highest GP $(45.8 \%)$ was obtained from the combination of $3 \mathrm{~s} \mathrm{SA}+4 \mathrm{~g}$ AS pretreatment in seeds with the highest germination percentage based on storage temperature $\left(15^{\circ} \mathrm{C}\right)$. In the combination of $6 \mathrm{~s} \mathrm{SA}+2 \mathrm{~g}$ AS pretreatment, which yielded the highest germination percentage among the pretreatments, germination was $27.7 \%$, $43.99 \%, 40.37$ and $21.16 \%$, respectively, depending on the increase in the storage temperatures (Table 3). High GP were obtained from scarification in sulfuric acid and scarification in sulfuric acid + floating in ash solution pretreatment combinations at all storage temperature degrees (Figure 2).

\section{Scarification Rates - Stupanj skarifikacije}

Sulfuric acid is a very strong acid, and its corrosive effect allows seed coats to become thinner. In this study, a statistically significant increase was detected in the scarification rates of the seed coats with the increase in the retention time in sulfuric acid (Table 5).

The rate of scarification increases in seed coats with increasing scarification times in sulfuric acid is an expected phenomenon. However, the scarification rate increasing with time is important to avoid damage of sulfuric acid to the seeds. When the application time increases in pretreatments with sulfuric acid, there is a possibility that acid will pass the seed coat and damage the embryo. Considering that the thickness was $0.90 \mathrm{~mm}$ in the measurements made in the thin parts of the seed coats, and this value can decrease to $0.10 \mathrm{~mm}$, it is seen that the likelihood of sulfuric acid reaching the embryo at the end of the 6-hour scarification period is high.

As a result, in the production of azarole seedlings, it may be recommended that the seeds should be stored at $15^{\circ} \mathrm{C}$ when they need to be stored, and that the seed coats should be scarified in $3 \mathrm{~h} \mathrm{SA}+4 \mathrm{~d}$ AS before sowing in August.

\section{ACKNOWLEDGEMENTS}

ZAHVALA

This study was supported by Artvin Coruh University Scientific Research Programs with the project numbered 2016F10.02.10. We thank the Scientific Research Programs for their financial support.

\section{REFERENCES \\ LITERATURA}

- Ahmadloo, F., M. Tabari, P. Azadi, A. Hamidi, 2014: Effect of plant growth promoting rhizobacteria (PGPRs) andstratification on germination traits of Crataegus pseudoheterophylla Pojark. Seeds, Scientia Horticulturae, 172: 61-67.

- Ahmadloo, F., M. Tabari Kochaksaraei, P. Azadi, A. Hamidi, E. Beiramizadeh, 2015: Effects of pectinase, BAP and dry storage on dormancy breaking and emergence rate of Crataegus pseudoheterophylla Pojark, New Forests, 46: 373-386.

- Ahmadloo, F., M. Tabari Kouchaksaraei, G. R. Goodarzi, A. Salehi, 2017: Effects of gibberellic acid and storage temperature on the germination of hawthorn seeds, J. For. Sci. , 63 (9): 417-424.

- Baskin, C. C., J. M. Baskin, 2014: Seeds (Ecology, Biogeography, and Evalution of dormancyand germination), Elsevier, 1586 p., USA

- Bell, D. T., 1999: The process of germination in Australian species, Australian Journal of Botany, 47: 475-517.

- Bewley, J. D., K. J. Bradford, H. W. M. Hilhorst, H. Nonogaki, 2013: Seeds, Physiology of Development, Germination and Dormancy, Third Edition, Springer, 392 p., London.

- Bujarska-Borkowska, B., 2002: Breaking of seed dormancy, germination and seedling emergence of the common hawthorn (Crataegus monogyna Jacq) Dendro Biology, 47: 61-70

- Bujarska-Borkowska, B., 2007: Dormancy breaking, germination, and seedling emergence from seeds of Crataegus submollis. Dendrobiology, 58: 9-15. 
- Compton, M. E., 1994: Statistical methods suitable for the analysis of plant tissue culture data, Plant Cell, Tissue and Organ Culture, 37: 217-242.

- Dirr, M. A., C. W. Jr. Heuser, 1987: The Reference Manual of Woody Plant Propagation, From Seed to Tissue Culture, Varsity Press., 239 p., Athens, GA.

- Donmez, A. A., 2004: The Genus Crataegus L. (Rosaceae) with Special Reference to Hybridisation and Biodiversty in Turkey, Turkish Journal of Botany, 28: 29-37.

- Göktürk, A., S. Guner, F. Yildirim, 2017: Seed Properties of Hawthorn (Crateagus sp.) Species and Effects of Sulfuric Acid Pretreatments on Seed Coat Thickness, In: D. Kovacevic (ed), VIII International Scientific Agriculture Symposium, East Sarajevo Faculty of Agriculture, 733-738, Bosnia and Herzegovina.

- Göktürk, A., S. Yilmaz, 2015: Investigation of the Effects of Sowing Area, Sowing time and Some Pretreatments on Germination of Seeds of Crataegus orientalis Paal. Ex. M. Bieb, Journal of Forestry Faculty of Artvin Coruh University, 16 (2): 190-202.

- Gupta, A., D. Singh, 1990: Viability of fungicide treated seeds of mung bean and cowpea in storage, Seed Research, 18, 70-76.

- Hartmann, H. T., D. E. Kester, Jr. F. T. Davies, R. L. Geneve, 2002: Hartmann and Kesters' plant propagation: principles and practices. 7th edition, 880 p., NJ: Prentice Hall.

- Hong, T. D., S. Linington, R. H. Ellis, 1996: Seed Storage Behaviour, A Compedium, Handbook for Genebanks, No. 4. International Plant Genetic Resources Institute, 104 p., Italy
- Hou, J. Q., G. M. Simpson, 1994: Effects of immersing dry seeds in alkaline solutions on seed dormancy and water uptake in wild oat (Avena fatua). Canadian Journal of Plant Science, 74: 19-24.

- ISTA (International Seed Testing Association), 1993: Rules for Testing Seeds, Rules, Seed Science and Technology, 259 p., Switzerland.

- Morgenson, G., 2000: Effects of cold stratification, warm-cold stratification, and acid scarification on seed germination of three Crataegus species. Tree Planters Notes, 49(3): 72-74.

- Prochazkova, Z., L. Bezdeckova, 2008: Effects of moisture content, storage temperature and type of storage bag on the germination and viability of stored European beech (Fagus sylvatica L.) seeds. Journal of Forest Science, 54 (7): 287-293.

- Schmidt, L., 2000: Guide to Handling of Tropical and Subtropical Forest Seed. Danida Forest Seed Centre, 511 p., Humlabaek, Denmark.

- Wang, J. H., C. C. Baskin, W. Chen, G. Z. Du, 2010: Variation in seed germination between populations of five sub-alpine woody species from eastern Qinghai-Tibet Plateau following dry storage at low temperatures. Ecological Research, 25: 195203.

- Yahyaoglu, Z., Z,. Olmez, A. Gokturk, F. Temel, 2006: Effectives on Germination of Seeds of Crataegus spp. of Cold Stratification and Sulfuric Acid Pretreatments. Journal of ZKU Bartin Forestry Faculty, 8 (10): 72-77.

\section{SAŽETAK}

Cilj ovoga istraživanja bio je utvrditi utjecaj temperature čuvanja na klijavost sjemena mušmulastog gloga (Crataegus azarolus var. pontica). Sjeme je prethodno obrađeno te je čuvano na suhom 10 mjeseci na četiri temperature čuvanja $\left(-5,5,15\right.$ i $\left.25^{\circ} \mathrm{C}\right)$. Predsjetvena priprema provedena je u različitim periodima plutanjem u vodi s otopljenim pepelom (2, 4 i 6 dana), skarifikacijom u sumpornoj kiselini ( 1,3 i 6 sati) te kombinacijom skarifikacije u sumpornoj kiselini i plutanjem u otopini pepela. Također, određen je stupanj skarifikacije sjemene ljuske koje su korodirale u sumpornoj kiselini 1, 3 i 6 sati. Eksperiment je dizajniran u slučajnom blok rasporedu s četiri ponavljanja. Kao rezultat istraživanja postignut je veći postotak $(20,95 \%)$ klijanja $(\mathrm{p}<0,05)$ kod sjemena čuvanog na $15{ }^{\circ} \mathrm{C}$. Rezultati pokazuju da skarifikacija u sumpornoj kiselini ima veći učinak ( $>0,05)$ na postotak klijanja sjemena mušmulastog gloga. Promjer sjemena koje je korodiralo u sumpornoj kiselini 1, 3 i 6 sati smanjio se redom za 6,15 \%, 10,47 \% i 11,51 \%. Za sjetvu u kolovozu, kako bi se postigao veći postotak klijavosti, sjeme mušmulastog gloga trebalo bi čuvati na $15^{\circ} \mathrm{C}$ i tretirati sumpornom kiselinom u trajanju od 3 sata te 4 dana u otopini pepela.

KLJUČNE RIJEČl: mušmulasti glog, temperatura čuvanja, granica klijavosti, skarifikacija, otopina pepela 